\title{
Remittances and the Dutch Disease in Sub-Saharan Africa: A Dynamic Panel Approach
}

\author{
Emmanuel Owusu-Sekyere ${ }^{1,2}$, Reneé van Eyden', Francis M Kemegue ${ }^{1,3}$
}

\begin{abstract}
This paper investigates the effect of remittance inflows on real exchange rates in sub-Saharan Africa (SSA) using annual data from 1980 to 2008 for 34 countries, the method of moments estimator developed by Arellano and Bover (1995) and the feasible generalized least squares estimator developed by Parks (1967) and Kmenta (1986). We find that when cross-sectional dependence and individual effects are controlled for, remittances to sub-Saharan Africa as a whole increase the underlying real exchange rates of recipient countries. However, this real exchange rate appreciation is mitigated by monetary policy interventions and the direction of fiscal expenditures towards tradable goods. Thus, the real exchange rate appreciation does not lead to the loss of export competitiveness or a worsening of the trade deficit in the countries in the panel.
\end{abstract}

KEY WORDS: $\quad$ Dutch disease; remittances; real exchange rate; sub-Saharan Africa

JEL Classification: $\quad$ C33; F24; F31; O55

${ }^{1}$ University of Pretoria, South Africa; ${ }^{2}$ Human Sciences Research Council (HSRC), South Africa;

${ }^{3}$ Framingham State University, USA

\section{Introduction}

Remittances to developing countries have reached significant levels over the last two decades. As of the end of 2008, global remittances totaled thrice the value of official development assistance to developing countries and exceeded $10 \%$ of GDP in 23 recipient countries worldwide (Mohapatra et al., 2009). Remittances to sub-Saharan Africa steadily increased from 1.4 billion US dollars in 1980 to 21.3 billion US dollars in 2008 , approximately $2.2 \%$ of regional

Correspondence concerning this article should be addressed to: Reneé van Eyden, University of Pretoria Department of Economics Private Bag X20 Hatfield Pretoria 0028 South Africa T: +27 834073053 Email: renee.vaneyden@up.ac.za
GDP (World Bank, 2008). It is further estimated that an additional amount equal to approximately $50 \%$ of formal inflows arrives in sub-Saharan Africa through informal channels (International Monetary Fund [IMF], 2006).

Research has demonstrated that significant increases in foreign inflows such as remittances could cause the underlying real exchange rate of the recipient economy to appreciate, adversely affecting export competitiveness and, consequently, the trade deficit (Corden and Neary, 1982). This would further result in the contraction of the tradable sector of the recipient economy, leading to a decline in the manufacturing and production of other tradable goods. Additionally, an increase in remittances - ceteris paribus - increases the disposable incomes of recipient households, leading to 
an increase in aggregate demand. This spending effect results in higher relative prices of non-tradable goods (i.e., goods produced and consumed domestically that are not close substitutes for imported or exported goods and services), as the prices of tradable goods (i.e., goods that are traded internationally and obey the law of one price or an appropriate relative pricing) are assumed to be exogenously given (Acosta, Lartey, \& Mandelman, 2007). The higher prices of non-tradable goods lead to an expansion of the non-tradable sector. Assuming that resources are perfectly mobile, there could be a reallocation of resources from the tradable to the non-tradable sector. In addition to this reallocation of resources, remittance-receiving households are also known to occasionally reduce labor supply (AmuedoDorantes \& Pozo, 2004). Assuming that resources are fully utilized, this could increase the marginal cost of labor in the tradable sector, leading to an increase in production costs and a further contraction of the tradable sector (Acosta et al., 2007). These adverse effects of an increase in foreign inflows (in this case, remittances) on the real exchange rate, the tradable sector, loss of export competitiveness, and consequently, the trade deficit are referred to as the Dutch disease effect of remittance inflows (Corden \& Neary, 1982). However, this is based on the assumption that households primarily spend remittances on non-traded goods. The Dutch disease effect of foreign inflows could also be influenced by other fundamental determinants of real exchange that depreciate the real exchange rate, thereby mitigating the appreciating effect of foreign inflows on the real exchange rate (Edwards 1989; 1994; Montiel, 1999). Furthermore, in certain countries, a specific policy stance by monetary authorities and conditionalities on development assistance have also been found to mitigate the natural macroeconomic transmission mechanism of foreign inflows (Nwachukwu, 2008; Oomes, 2008).

The impact of foreign inflows on the real exchange rate has been found to vary from region to region. In a study on foreign aid and the real exchange rate in 12 francophone West African countries, Quattara and Strobl (2004) found that foreign aid flows do not generate Dutch disease effects. Similar results were obtained by Ogun (1995) for Nigeria and Nyoni (1998) for Tanzania. On the contrary, Elbadawi (1999), in a study of 62 developing countries, and White and
Wignaraja (1992), for Sri Lanka, reported that aid flows appreciated the real exchange rates of the recipient countries in their study. Conflicting results were also observed in studies of foreign aid and the real exchange rate in Ghana. While Sackey (2001) found no appreciating effect on the real exchange rate, OpokuAfari, Morrissey and Lloyd (2004) found the opposite and support for the Dutch disease theory. Using annual data on six Central American countries from 1985 to 2004, Izquierdo and Montiel (2006) found the real exchange rate to be relatively stable despite increased remittance inflows. In other cases such as the Euro-Mediterranean region, remittance inflows appreciated the real exchange rate but did not result in a deterioration of the current account balance, although exports suffered to some extent (Oomes, 2008). These disparities in findings by those authors (Nyoni, 1998; Quattara \& Strobl, 2004; Ogun, 1995; Sackey, 2001), on one hand, who found no effect of foreign inflows on the international competitiveness of recipient countries and those (Elbadawi, 1999; Izquierdo and Montiel, 2006; Opoku-Afari et al., 2004; White \& Wignaraja, 1992), on the other hand, who found that foreign inflows adversely affected the international competitiveness of recipient countries merit the need to ascertain the precise impact of remittance inflows on the international competitiveness of recipient countries in sub-Saharan Africa.

The objective of this paper is to examine the impact of remittances on the real exchange rate using annual data from 1980 to 2008 for 34 sub-Saharan African (SSA) countries. Do remittances appreciate the real exchange rate of the recipient countries in the panel? If yes, does it lead to a loss of export competitiveness and a deterioration of the trade deficit? If no, is this because the appreciating effect is mitigated by fundamental determinants of the real exchange rate or an intervention by monetary authorities in pursuit of a specific monetary policy objective, such as maintaining export competitiveness or a sustainable current account deficit? We adopt the theoretical framework of Montiel (1999), which states that the real exchange rate is an endogenous variable and is in equilibrium when it is simultaneously consistent with internal and external balances and conditional on longrun fundamentals (sustainable values of exogenous and policy variables). Internal balance refers to the situation in which the non-tradable goods market clears in the 
current period and is expected to be in equilibrium in the future (Montiel 1999). Thus, assuming initial internal balance equilibrium, an increase in private spending creates excess demand for non-tradable goods at the initial exchange rate. An appreciation of the real exchange rate would then be required to restore equilibrium. This would - ceteris paribus - lead to an increase in the supply of non-tradable goods and an increase in demand for tradable goods. The external balance, however, is defined as the current account balance that is consistent with sustainable long-run capital inflows (Montiel, 1999). This is determined by the domestic output of traded goods net of domestic consumption, plus net aid flows, less the cost of foreign debt. From the perspective of initial external balance equilibrium, an increase in private spending generates a current account deficit at the initial exchange rate. A real depreciation would therefore be required in this case to restore equilibrium. This leads to an increase in the supply of tradable goods and an increase in the demand for non-tradable goods.

The Montiel (1999) model states that factors affecting internal and external balance would also cause changes in the long-run equilibrium real exchange rate. These factors include fiscal policy, international transfers, terms of trade, total factor productivity, international financial conditions and commercial policy (see Montiel, 1999 and 2003, for complete details on the theoretical framework).

Most studies on the impact of foreign inflows on the real exchange rate in sub-Saharan Africa have primarily focused on official development assistance and devoted scant attention to remittances. Second, most of them have examined specific countries in sub-Saharan Africa such as Tanzania (Nyoni, 1998), Nigeria (Ogun, 1995), Ghana (Opoku-Afari et al., 2004; Sackey 2001) and rarely sub-regions within sub-Saharan Africa such as francophone West Africa (Ouattara \& Strobl, 2004) or sub-Saharan Africa as a whole (Nwachukwu, 2008). This paper therefore contributes to the limited literature on remittance inflows into Sub-Saharan Africa and their effect on the real exchange rate, using annual data on 34 sub-Saharan African countries from 1980 to 2008 and dynamic panel estimation techniques, namely the feasible generalized least squares (FGLS) approach developed by Parks (1967) and Kmenta (1986) and the two-step system generalized methods of moments (GMM) proposed by Arellano and Bover
(1995). This paper differs from most previous work by testing for cross-sectional dependence in the error term among the countries in the panel using the Pesaran (2004) CD test and controlling for it using appropriate dynamic panel estimation techniques.

In the context of remittances, cross-sectional dependence is caused by the spillover effect of remittances across borders in the sub-Saharan African region. African countries have migrants from neighboring countries who receive remittances from their relatives in the diaspora. Labor mobility (both skilled and unskilled) and cross-border trade are highly prevalent within the region. This indicates that non-recipient households also benefit from remittance inflows through labor income and recipient households' demand for goods and services (Durrand, Parrado, \& Massey, 1996). These factors (intraAfrican migration, labor mobility, cross-border trade and the multiplier effect of remittance flows) create spillover effects that have not been adequately addressed in the remittances literature on sub-Saharan Africa.

By addressing this gap in the sub-Saharan Africa remittances literature, we also control for a major assumption of panel data estimations, namely, cross-sectional independence. In the presence of cross-sectional dependence of the error term, methods employing instrumental variable estimations and the generalized method of moments (GMM) - such as those proposed by Anderson and Hsiao (1981), Arellano and Bond (1991), and Blundell and Bond (1998) - yield inconsistent estimates. Such inconsistency is exacerbated if one employs a short dynamic panel data model with a fixed $T$ (the panel time dimension) as $N$ (the cross-sectional dimension) grows large (Sarafidis \& Robertson, 2009).

The remainder of this paper is structured as follows: section 2 describes the data and methodology, section 3 discusses empirical results, and section 4 contains the conclusions, policy recommendations and suggestions for future research.

\section{Data and methodology}

Table 1 below details the data series used and the measurement thereof. Following Montiel (1999, 2003), the fundamental determinants of the real exchange rate used in this paper include international transfers (remittances), fiscal expenditures (government final expenditure on goods and services), terms of trade, current account openness, international financial conditions 
Table 1. Sources and definition of variables

\begin{tabular}{|c|c|c|c|}
\hline & Variable & Source & Definition \\
\hline rer & Real exchange rate & IMF, World Bank & $\begin{array}{l}\text { The real exchange rate is measured as the product of the } \\
\text { nominal bilateral exchange rate with the USD and the ratio } \\
\text { of the US wholesale price index to domestic prices (GDP } \\
\text { deflator, } 2005=100 \text { ) in each country. }\end{array}$ \\
\hline rem & $\begin{array}{l}\text { Remittances as a percentage of } \\
\text { GDP (International transfers) }\end{array}$ & World Bank & $\begin{array}{l}\text { Workers' remittances as a percentage of GDP in current prices } \\
\text { (USD Millions). }\end{array}$ \\
\hline $\mathrm{fp}$ & Fiscal policy & World Bank & $\begin{array}{l}\text { Government final consumption as a percentage of GDP in } \\
\text { SSA countries (a proxy for the direction of fiscal expenditure). }\end{array}$ \\
\hline open & Current account openness & Penn World Table PWT 7.0 & $\begin{array}{l}\text { The ratio of the sum of exports and imports of goods and } \\
\text { services to GDP in SSA countries. }\end{array}$ \\
\hline idif & Interest rate differential & IMF, World Bank & $\begin{array}{l}\text { Differential between the deposit interest rates in SSA } \\
\text { countries and the USA. }\end{array}$ \\
\hline m2 & Monetary policy effects & IMF, World Bank & $\begin{array}{l}\text { Quasi money as a percentage of GDP (a measure of monetary } \\
\text { policy interventions). }\end{array}$ \\
\hline tot & Terms of trade & World Bank & Ratio of export prices to import prices for SSA countries. \\
\hline
\end{tabular}

(interest rate differential between sub-Saharan African countries and the USA) and quasi money (M2) as a percentage of GDP, as a proxy for monetary policy effects.

The USA is employed as a "representative" host country for a number of reasons. The dominant destinations of migrants from the 34 sub-Saharan African (SSA) countries in this panel are UK, USA and Canada (for the Anglophone SSA countries); France and Belgium (for the Francophone SSA countries); and South Africa (for the SADC countries). An alternative approach would be to construct an index based on the weights of the GDP per capita of these six countries and use them to represent host country income/economic conditions. However, the annual GDP per capita measures of these six countries are highly positively correlated (above 0.98) due to the impact of global business cycle trends and global economic integration among these six countries. A graphical analysis of the GDP per capita of the six countries indicates that the GDP per capita of the other countries closely mirrors trends in the GDP per capita of the USA. The USA, Canada, France and Belgium are highly linked through EU-USA business cycle linkages, while the EU is the largest export destination for South Africa. Furthermore, the USA is a major trading partner for most of the countries in the panel. Thus, most African currencies are pegged to the US dollar (USD) in foreign exchange reserves. The USA also represents the largest source of capital flows to African countries. Consequently, the USA has a strong impact on real exchange rate/interest rate differential dynamics in the countries in this panel. For these reasons, we use the largest/strongest economy of these dominant migration destinations (the USA) as a "representative" host country. It is also the only country where a "representative migrant" (not all or most of the migrants) from each of the 34 countries can be found.

Data on all variables for the sub-Saharan African countries in the panel, including Benin, Burundi, Botswana, Burkina Faso, Cameroun, Cape Verde, Comoros, Cote D'Ivoire, Ethiopia, Gabon, The Gambia, Ghana, Guinea, Guinea-Bissau, Kenya, Lesotho, Madagascar, Malawi, Mali, Mauritius, Mauritania, Mozambique, Niger, Nigeria, Rwanda, Senegal, the Seychelles, Sierra Leone, Swaziland, South Africa, Tanzania, Togo, Uganda, and Zambia are obtained from the World Development Indicators of the World Bank, complemented with data from the International Monetary Fund.

Table 2 details the relationship between the variables employed and the real exchange rate. This forms the basis of our a priori expectations.

\subsection{Model specification and estimation technique}

Cross-correlation analysis reveals that the real exchange rate exhibits strong persistence behavior. This warrants 
Table 2. A priori expectations. Dependent variable: rer

\begin{tabular}{|c|c|c|}
\hline Variable & Sign & Inference \\
\hline rem & Positive/ negative & $\begin{array}{l}\text { Remittances improve the foreign reserve position of recipient countries, which should } \\
\text { appreciate the domestic currency (negative relationship). If remittances were spent on } \\
\text { tradables, then it would have a depreciating effect on the real exchange rate (positive } \\
\text { relationship). }\end{array}$ \\
\hline $\mathrm{fp}$ & Positive/ negative & $\begin{array}{l}\text { Fiscal expenditures on traded goods would have a depreciating effect on the real } \\
\text { exchange rate (positive relationship). If they target non-traded goods, then they } \\
\text { would have an (negative) appreciating effect on the real exchange rate. }\end{array}$ \\
\hline tot & Positive/ negative & $\begin{array}{l}\text { An export-dominated terms of trade would appreciate the real exchange rate } \\
\text { (negative relationship), while an import-dominated terms of trade would depreciate } \\
\text { the real exchange rate (positive relationship). }\end{array}$ \\
\hline open & Positive/ negative & $\begin{array}{l}\text { An export-dominated foreign sector would appreciate the real exchange rate } \\
\text { (negative relationship); an import-dominated foreign sector would depreciate the real } \\
\text { exchange rate (positive relationship). }\end{array}$ \\
\hline idif & Negative & $\begin{array}{l}\text { A positive interest rate differential should attract foreign inflows that should } \\
\text { appreciate the real exchange rate (negative relationship). }\end{array}$ \\
\hline $\mathrm{m} 2$ & Negative/ positive & $\begin{array}{l}\text { Monetary policy interventions (sterilization) designed to depreciate the real exchange } \\
\text { rate would have a positive relationship with the real exchange rate and a negative } \\
\text { relationship if it is intended to appreciate the real exchange rate. }\end{array}$ \\
\hline
\end{tabular}

employing a dynamic panel data model that includes one or more lags of the dependent variable. We specify a two-way error component model based on the heterogeneity among the 34 countries in the panel and various developments at different time periods that significantly affected exchange rate developments in sub-Saharan African during the sample period. These time effects include nominal devaluations by countries, oil price shocks and political instability at various time periods in different countries, all of which had varying effects on the nominal and, consequently, real exchange rates of the countries in the panel. These developments, especially political conflicts, also had spillover effects within the region. The model is therefore specified in (1) as

$y_{i t}=\delta y_{i, t-1} X_{i t}^{\prime} \beta+\mu_{i}+\lambda_{t}+v_{i t}$

where $y_{i t}$ is an NT $x 1$ vector of dependent and endogenous variables. $X_{i t}^{\prime}$ represents an NT $x k$ vector of independent regressors other than the lag of the dependent variable, $\beta$ denotes a $k x m$ vector of slope coefficients, $\mu_{i}$ represents country-specific effects, $\lambda_{t}$ time effects and $v_{i t}$ the idiosyncratic error term. Equation (1) is based on the assumption of exogeneity of the regressors. However, by construction, the lag of the dependent variable $y_{i, t-1}$ is correlated with the fixed-effects $\mu_{i}$ error term. Additionally, the terms of trade variable is correlated with the error term. Consequently, the Hausman specification test rejects the null of the exogeneity of all right-hand-side regressors in (1). A general LM-test for heteroskedasticity (Greene, 2003) indicates the existence of heteroskedasticity in the specification. The modified Wald test rejects the null of group-wise homoskedasticity, implying a non-constant variance across cross-sections. However, it is known to have very low power in the context of fixed effects when $N>T$ (Greene, 2003). This test is therefore not reported but controlled for in the analysis. Table 3 details the results of the initial diagnostic tests performed on the pooled ordinary least squares (POLS) and fixed-effects (FE) models.

In addition to the presence of endogeneity, the two-way fixed-effect model specified in (1) also suffers from first-order serial correlation. Furthermore, a test for cross-sectional dependence of the error terms using the Pesaran (2004) CD test rejects the null of cross-sectional independence at the $1 \%$ level of significance, with an average cross-sectional correlation coefficient of 0.42 .

To establish the order of integration of the dataset, we employ the Pesaran (2007) cross-sectionally adjusted 
Table 3. Initial diagnostic tests

\begin{tabular}{|c|c|c|c|}
\hline Test & Test statistic & Critical value & Inference \\
\hline $\begin{array}{l}\text { Joint validity of cross-sectional individual effects } \\
H_{0}: \mu_{1}=\mu_{2} \ldots \mu_{N-1}=0 \\
H_{A}: \text { Not all equal to } 0\end{array}$ & $F=15.12$ & $F(0.05,34,939)=1.442$ & $\begin{array}{c}\text { Cross-section-specific effects } \\
\text { are valid. }\end{array}$ \\
\hline $\begin{array}{l}\text { Joint validity of time (period) effects } \\
H_{0}: \lambda_{1}=\ldots \lambda_{T-1}=0 \\
H_{A}: \text { Not all equal to } 0\end{array}$ & $F=44.51$ & $F(0.05,27,947)=1.498$ & $\begin{array}{l}\text { Time effects are valid. The error } \\
\text { term takes a two-way error } \\
\text { component form. }\end{array}$ \\
\hline $\begin{array}{l}\text { Heteroskedasticity } \\
H_{0}: \sigma_{i}^{2} \sigma^{2} \\
H_{A}: \text { Not equal for all } i\end{array}$ & $L M=817.59$ & $\chi_{(34)}^{2} 48.60$ & $\begin{array}{l}\text { The variance of the error } \\
\text { term is not constant. } \\
\text { Heteroskedasticity is present. }\end{array}$ \\
\hline $\begin{array}{l}\text { Hausman specification test } \\
H_{0}: E\left(u_{i t} \mid X_{i t}\right)=0 \\
H_{A}: E\left(u_{i t} \mid X_{i t}\right) \neq 0\end{array}$ & $m_{3}=160.11$ & $\chi_{(7)}^{2} 12.60$ & Regressors not exogenous. \\
\hline $\begin{array}{l}\text { Pesaran (2004) CD test for cross-sectional } \\
\text { dependence } \\
H_{0}: \operatorname{corr}\left(u_{i t}, u_{j t}\right)=0 \text { for } i \neq j \\
H_{A}: \operatorname{corr}\left(u_{i t}, u_{j t}\right)=0 \text { for some } i \neq j\end{array}$ & $C D=5.2(0.42)$ & Prob $=0.000$ & $\begin{array}{l}\text { Cross-sections are } \\
\text { interdependent. }\end{array}$ \\
\hline
\end{tabular}

Dickey-Fuller (CADF) Test. The Pesaran (2007) CADF test is well suited to heterogeneous panel data with cross-sectional dependence in the errors, as is the case in this study. It assumes a null hypothesis of non-stationarity of the data series. In the Pesaran (2007) CADF test, the cross-sectional dependence is eliminated by augmenting Dickey-Fuller (or Augmented DickeyFuller) regressions with the cross-sectional averages of lagged levels and first-differences of the individual series (CADF statistics). The results of unit root tests are reported in Table 4. The variables rer, $m 2$, rem and open are found to be non-stationary I(1), while $f p$, tot and idif are stationary.

The results of the initial diagnostic tests warrant the use of an estimation technique that preserves homoskedasticity, controls for cross-sectional dependence and preserves the orthogonality between transformed variables and lagged regressors (Arellano and Bover, 1995). Two estimation techniques meet these criteria, namely the feasible generalized least squares (FGLS) technique developed by Parks (1967) and Kmenta (1986) and the two-step system generalized method of moments (GMM) proposed by Arellano and Bover (1995).
The Parks and Kmenta FGLS estimation technique is perfectly suited to data with individual effects, group-wise heteroskedasticity, serial correlation and cross-sectional dependence in the error term (Hicks, 1994; Kmenta, 1986). The FGLS estimation technique is suitable whether the individual effects are fixed over time and cross-sections or are normally distributed random variables. It involves two sequential transformations. First, it eliminates serial correlation in the errors and then the contemporaneous correlation of the errors across cross-sections, which also automatically corrects for panel heteroskedasticity (Beck \& Katz, 1995). This is achieved by initially estimating a pooled model. Residuals from this initial estimation are used to estimate the unit-specific serial correlation of the errors, which are then used to transform the model into one with serially independent errors. The residuals from this estimation are then used to estimate the contemporaneous correlation of the errors, and the data is again transformed to allow for an estimation without any complications in the errors. This process yields consistent estimators of the elements of the variance-covariance matrix, which then yields the desired 
Table 4. Pesaran (2007) Cross-sectional Augmented Dickey-Fuller (CADF) unit root test

\begin{tabular}{|c|c|c|c|c|c|c|c|}
\hline & rer & $f p$ & tot & idif & $\mathrm{m} 2$ & rem & open \\
\hline \multicolumn{8}{|l|}{$\begin{array}{c}\text { Pesaran (2007) } \\
\text { t-stat }\end{array}$} \\
\hline $\begin{array}{c}\text { Levels } \\
\text { [P-value] }\end{array}$ & $\begin{array}{l}1.320 \\
{[0.99]}\end{array}$ & $\begin{array}{c}-2.113^{* *} \\
{[0.017]}\end{array}$ & $\begin{array}{r}-1.974^{*} \\
{[0.09]}\end{array}$ & $\begin{array}{c}-2.017^{* *} \\
{[0.06]}\end{array}$ & $\begin{array}{l}-1.574 \\
{[0.869]}\end{array}$ & $\begin{array}{r}-1.715 \\
{[0.67]}\end{array}$ & $\begin{array}{r}-1.689 \\
{[0.67]}\end{array}$ \\
\hline $\begin{array}{c}\text { Differences } \\
\text { [P-value] }\end{array}$ & $\begin{array}{c}-3.942^{* * *} \\
{[0.00]}\end{array}$ & -- & -- & -- & $\begin{array}{c}-3.258^{* * *} \\
{[0.00]}\end{array}$ & $\begin{array}{c}-3.499 * * * \\
{[0.00]}\end{array}$ & $\begin{array}{c}-3.644^{* * *} \\
{[0.00]}\end{array}$ \\
\hline
\end{tabular}

Note: ${ }^{* *} / * * *$ denote $1 / 5 / 10$ percent levels of significance, respectively. Statistical insignificance implies failing to reject the null of non-stationarity; p-values in [ ]. Critical values at 1/5/10 percent available in Pesaran (2007) and in test results output in STATA 11.

coefficient estimates and their respective standard errors (Kmenta, 1986). The FGLS estimation is, however, known to lose some degree of efficiency when there is endogeneity from regressors other than the lagged dependent variable (Kmenta, 1986). Thus to ensure robustness, we also employ the two-step system GMM estimation technique of Arellano and Bover (1995).

In the two-step system GMM, the endogeneity problem is addressed by time demeaning the data to remove time effects. Time demeaning the data is equivalent to including common time effects to capture "common trends" in the variation of the dependent variable across cross-sections. Time demeaning the data reduces cross-sectional dependence "but only to a certain extent" (De Hoyos \& Sarafidis, 2006). As we have a moderate level of cross-sectional dependence in this paper (cross-correlation coefficient of 0.42 ), time demeaning the data prior to the GMM estimation should partially or sufficiently control for it. The cross-section specific effects are then eliminated using forward orthogonal deviations, thereby making it possible to use one-period lags of the regressors as valid instruments, as they are not correlated with the transformed error term (Love \& Zichinno, 2006). We estimate the two-step system GMM while collapsing the lag range to avoid instrument proliferation and apply the Windmeijer (2005) correction for heteroskedasticity to ensure robust standard errors. Another advantage of this approach is that it is more resilient to missing data. It is computable for all observations except for the last for each cross-section, thereby minimizing data loss (Roodman, 2006).

\section{Empirical results}

The FGLS and the two-step system GMM estimations yield similar results. Table 5 details the empirical results. The FGLS estimation specified that the errors of the panels are correlated. The two-step system GMM estimation involves forward orthogonal deviations instead of differencing (Arellano and Bover, 1995). The OLS results are significantly different from the FGLS and two-step system GMM results due to violations of the assumptions of the classical linear regression model, as reported in the results of initial diagnostics in Table 3.

As expected, the real exchange rate exhibits strong persistence behavior that is significant at the $1 \%$ level. The coefficient of remittance inflows is negatively signed and statistically significant at the $1 \%$ level. This means that remittances on average have an appreciating effect on the real exchange rates of the recipient sub-Saharan African countries in the panel.

Fiscal expenditure is positively signed and statistically significant at the $1 \%$ level. This indicates that government expenditure is more targeted towards traded goods, with the economy requiring an exchange rate depreciation to restore external balance. The coefficient of terms of trade is negatively signed and statistically significant at the $1 \%$ level, indicating an appreciating effect on the real exchange rate. This denotes that the income effect dominates the substitution effect of an improvement in the terms of trade, requiring an appreciation of the real exchange rate to restore external balance. Current account openness is also negatively signed and statistically significant at the $1 \%$ level. This indicates an export-dominated foreign 
Table 5. Empirical results: FGLS and two-step system GMM. Dependent variable: rer

\begin{tabular}{|c|c|c|c|}
\hline Variable & OLS & FGLS & Two-step system GMM \\
\hline $\operatorname{rer}(-1)$ & $\begin{array}{l}0.90^{* * *} \\
(32.14)\end{array}$ & $\begin{array}{l}0.79 * * * \\
(42.80)\end{array}$ & $\begin{array}{l}0.75^{* * *} \\
(32.38)\end{array}$ \\
\hline rem & $\begin{array}{l}0.28^{* *} \\
(2.12)\end{array}$ & $\begin{array}{l}-3.05^{* * *} \\
(-3.03)\end{array}$ & $\begin{array}{l}-3.20^{* * *} \\
(-2.22)\end{array}$ \\
\hline$f p$ & $\begin{array}{c}-1.84^{* * *} \\
(-3.58)\end{array}$ & $\begin{array}{l}1.04^{* * *} \\
(8.49)\end{array}$ & $\begin{array}{c}1.07^{* * *} \\
(6.68)\end{array}$ \\
\hline tot & $\begin{array}{l}-0.08^{* *} \\
(-2.00)\end{array}$ & $\begin{array}{l}-0.72^{* * *} \\
(-5.99)\end{array}$ & $\begin{array}{l}-0.99 * * * \\
(-6.17)\end{array}$ \\
\hline open & $\begin{array}{l}-0.11^{* *} \\
(-2.14)\end{array}$ & $\begin{array}{l}-0.64^{* * *} \\
(-5.53)\end{array}$ & $\begin{array}{l}-0.93^{* * *} \\
(-3.23)\end{array}$ \\
\hline idif & $\begin{array}{c}0.08 \\
(1.33)\end{array}$ & $\begin{array}{c}0.81^{* * *} \\
(4.32)\end{array}$ & $\begin{array}{c}0.71^{* * *} \\
(9.83)\end{array}$ \\
\hline$\Delta m^{2}$ & $\begin{array}{l}-0.52^{* * *} \\
(-3.46)\end{array}$ & $\begin{array}{c}1.21^{* * *} \\
(2.68)\end{array}$ & $\begin{array}{c}2.88^{* * *} \\
(3.32)\end{array}$ \\
\hline Adjusted $R^{2}$ & 0.98 & & \\
\hline $\begin{array}{c}\text { A Bond test for second-order } \\
\text { serial correlation }\end{array}$ & & & Prob $>z=0.29$ \\
\hline $\begin{array}{l}\text { Hansen test for over- } \\
\text { identification }\end{array}$ & & & Prob $\chi^{2}>=.36$ \\
\hline $\begin{array}{l}\text { Diff. in Hansen test for } \\
\text { exogeneity of instrument set }\end{array}$ & & & Prob $\chi^{2}>=.37$ \\
\hline
\end{tabular}

Notes: ${ }^{* * * * * *}$ denote 10/5/1 percent levels of significance, respectively. T-statistics are in parentheses. When performing the Hansen test for over-identification, the "collapse" option in STATA was used to reduce the lag range and avoid instrument proliferation, in conjunction with the Windmeijer (2005) correction for robust standard errors.

sector on average and hence an appreciating effect on the real exchange rate. Contrary to a priori expectations, the interest rate differential is positively signed and statistically significant at the $1 \%$ level, which denotes a depreciating effect on the real exchange rate of a recipient country following an increase in the home country interest rate relative to the host country interest rate. This result may be attributed to the fact that remittances are less responsive to changes in the interest rate differential, over and above the fact that it only constitutes a portion of total inflows to any recipient country. The monetary policy variable is positively signed and statistically significant at the $1 \%$ level. This denotes that monetary policy is formulated to keep the exchange rate low probably to ensure a sustainable current account deficit. This provides an indication of the mitigating effect of monetary policy interventions such as sterilization on the appreciation of the real exchange rate. Such monetary policy intervention by countries is generally intended to maintain a real exchange rate that ensures export competitiveness and a sustainable current account deficit.

The two-step system GMM estimation satisfies all post-estimation diagnostic requirements. The Arellano and Bond (1991) test for second-order serial correlation fails to reject the null of no autocorrelation. The Hansen (1982) test for over-identification fails to reject the null that the over-identification restrictions 
are valid, while the Difference-in-Hansen test also fails to reject the null that the instrument subset is strictly exogenous.

\section{Conclusions, policy recommendations and future research}

The empirical results demonstrate that when crosssectional dependence and individual effects are controlled for, remittance inflows on average appreciate the underlying exchange rate of the recipient economies in this study. This is consistent with the Dutchdisease theory of Corden and Neary (1982). However, this appreciating effect of remittance inflows on the real exchange rate is mitigated by monetary policy interventions and the direction of fiscal expenditure.

Monetary policy is formulated to maintain a low real exchange rate, despite the steady increases in the rate of inflation observed for the countries in the panel. This prevents remittance inflows from exerting their natural transmission effect on the real exchange rate. It then implies that the nominal exchange rate is managed to some extent in most of the countries in the panel. This aligns with the findings of Oomes (2008) on Armenia and Nwachukwu (2008) on sub-Saharan Africa, who cite policy interventions as the mitigating factor for the appreciating effect of foreign inflows on the real exchange rate.

In addition to the monetary policy stance, the direction of fiscal expenditure increases the likelihood that fiscal expenditure is more targeted towards tradables than non-tradables, hence its depreciating effect on the real exchange rate. This is understandable due to the rather low levels of production capacity in the sub-Saharan African countries in the panel and hence these economies' substantial dependence on imports. Consequently, a deteriorating current account deficit is more likely due to over-dependence on imports than a loss of export competitiveness resulting from the impact of remittance inflows on the real exchange rate.

\section{References}

Acosta, A. P., Lartey, E. K. K., \& Mandelman, S. F. (2007). Remittances and the Dutch disease (Working Paper No. 2007-08). Federal Reserve Bank of Atlanta.

Amuedo-Dorantes, C., \& Pozo, S. (2004). Workers' remittances and the real exchange rate: a paradox of gifts. Journal of World Development, 32 (8), 1407-1417.
Anderson, T. W., \& Hsiao, C. (1982). Formulation and estimation of dynamic models using panel data. Journal of Econometrics, 18 (1), 47-82.

Arellano, M., Bond, S. (1991). Some tests of specification for panel data: Monte Carlo evidence and an application of employment equations. Review of Economic Studies, 58 (2), 277-297.

Arellano, M., \& Bover, O. (1995). Another look at the Instrumental Variable Estimation of Error Component Models. Journal of Econometrics, 68 (1), 29-52.

Beck, N., \& Katz, J.N. (1995). What to do (and not to do) with Time-Series Cross-Section Data. American Political Science Review, 89, 634-47.

Blundell, R., \& Bond, S. (1998). Initial conditions and moment restrictions in dynamic panel data models. Journal of Econometrics, 87 (1), 115-143.

Corden, W. M., \& Neary, J. P. (1982). Booming Sector and De-Industrialisation in a Small Open Economy. Economic Journal, 92 (368), 825-848.

De Hoyos, R.E., \& Sarafidis, V. (2006). Testing for cross-sectional dependence in panel data models. The Stata Journal, 6 (4), 482-496.

Durrand, J., Parrado, A., \& Massey, D. (1996). Migradollars and Development: A Reconsideration of the Mexican Case. International Migration Review, 30 (2), 423-444.

Edwards, S. (1989). Real exchange rates, devaluation and adjustment: exchange rate policy in developing countries. Cambridge, MA: The MIT Press.

Edwards S. (1994). 'Real and monetary determinants of real exchange rate behaviour: Theory and evidence from developing countries'. In J. Williamson (Ed.), Estimating equilibrium exchange rates (pp. 61-91). Washington, DC: Institute for International Economics.

Elbadawi, I.A. (1999). External Aid: Help or Hindrance to Export Orientation in Africa. Journal of African Economies, 8 (4), 578-616.

Greene, W. H. (2003). Econometric Analysis, $5^{\text {th }}$ Edition. New Jersey, NJ: Prentice Hall

Hansen, L. P. (1982). Large Sample Properties of Generalised Method of Moments Estimators. Econometrica, 50 (4), 1029-1054.

Hicks, A. (1994). Introduction to Pooling. In T. Janoski, \& A. Hicks (Eds.), The Comparative Political Economy of the Welfare State (pp. 169-188). Cambridge, UK: Cambridge University Press. 
International Monetary Fund. (2006). Balance of Payment Statistics Yearbook. Washington: International Monetary Fund. Retrieved from https://www.imf.org/external/pubs/cat/longres. cfm? sk $=20688.0$

Izquierdo, A., \& Montiel, P. J. (2006). Remittances and Equilibrium Real Exchange Rates in Six Central American Countries [Unpublished Manuscript]. Retrieved from http://idbdocs.iadb.org/wsdocs/ getdocument.aspx?docnum $=1640741$

Kmenta, J. (1986). Elements of Econometrics (2 ${ }^{\text {nd }}$ ed.). New York, NY: McMillan.

Love, I., \& Zicchino, L. (2006). Financial Development and Dynamic Investment Behaviour: Evidence from Panel VAR. The Quarterly Review of Economics and Finance, 46 (2), 190-210.

Mohapatra, S., Ratha, D., \& Silwal, A. (2009). Migration and Remittance Trends in 2009. (Migration and Development Brief, 11), World Bank.

Montiel, P. J. (1999). Determinants of the long-run equilibrium real exchange rate: an analytical model, In L. E. Hinkle \& P. J. Montiel (Eds.), Exchange Rate Misalignment: Concepts Measurement for Developing Countries (pp. 264-289). New York, NY: Oxford University Press.

Montiel, P. J. (2003). Macroeconomics in emerging markets. Cambridge, UK: University Press.

Nwachukwu, J. (2008). Foreign Capital Inflows, Economic Policies and the Real Exchange Rate in Sub Saharan Africa: Is there an interaction Effect? (Working Paper No. 25). Brooks World Poverty Institute.

Nyoni, T. (1998). Foreign Aid and Economic Performance in Tanzania. World Development 26 (7), 1235-1240.

Ogun, O. (1995). Real Exchange Rate Movements and Export Growth in Nigeria, 1960-1990 (Research Paper No. 82). African Economic Research Consortium.

Oomes, N. (2008). Coping with Strong Remittances: The Case of Armenia. Washington International Monetary Fund. D.C. [PowerPoint slides]. Retrieved from https://www.imf.org/external/np/seminars/ eng/2007/kazakhstan/oomesppt.pdf

Opoku-Afari, M., Morrissey, O., \& Lloyd, T. (2004). Real Exchange Rate Response to Capital Inflows: A Dynamic Analysis for Ghana (Research Paper No. 04/12). Centre for Research in Economic Development and International Trade, University of Nottingham.
Ouattara, B. \& Strobl, E. (2004). Foreign Aid Inflows and the Real Exchange Rate in the CFA Franc Zone (Research Paper No. 04/07). Centre for Research in Economic Development and International Trade, University of Nottingham.

Parks, R. W. (1967). Efficient Estimation of a System of Regression Equations when Disturbances are both Serially and Contemporaneously Correlated. Journal of the American Statistical Association, 62 (318), 500-509.

Pesaran, H. M. (2007). A Simple Panel Unit Root Test in the Presence of Cross Section Dependence, Journal of Applied Econometrics, 22 (2), 265-312.

Pesaran, M. H. (2004). General Diagnostic Tests for Cross Section Dependence in Panels (Working Paper No. 0435). University of Cambridge.

Roodman, D. (2006). How to do xtabond2: An Introduction to "Difference" and "System" GMM in Stata (Working Paper No. 103). Centre for Global Development.

Sackey, H. A. (2001). External Aid Inflows and the Real Exchange Rate in Ghana (Research Paper No. 110). African Economic Research Consortium.

Sarafidis, V. \& Robertson, D. (2009). On the impact of error cross-sectional dependence in short dynamic panel estimation, Econometrics Journal, Royal Economic Society, 12 (1), 62-81.

White, H, \& Wignaraja, G. (1992). Exchange Rates, Trade Liberalisation and Aid. The Sri Lankan Experience. World Development, 20 (10), 1471-1480.

Windmeijer, F. (2005). A finite sample correction for the variance of linear efficient two-step GMM estimators. Journal of Econometrics, 126 (1), 25-51.

World Bank. (2008). Migration and Remittances Factbook 2008, Washington, DC: The Wolrd Bank. Retrieved from http://www-wds.worldbank.org/ external/default/WDSContentServer/IW3P/IB/ 2008/03/14/000333038_20080314060040/Rendered/PDF/429130PUB0Migr101OFFICIAL0US E0ONLY1.pdf 